\title{
Accounting
}

\section{The effect of company performance on audit committee diligence: The case of manufacturing companies in Saudi Arabia}

\author{
Khaled Salmen Aljaaidi ${ }^{a^{*}}$ and Omar Ali Bagais ${ }^{a}$
}

${ }^{a}$ Department of Accounting, College of Business Administration, Prince Sattam bin Abdulaziz University, Saudi Arabia

\begin{tabular}{l}
\hline C H R O N I C L E \\
\hline Article history: \\
Received: September 25, 2020 \\
Received in revised format: \\
September 302020 \\
Accepted: November 7, 2020 \\
Available online: \\
November 8, 2020 \\
\hline Keywords: \\
Company experience \\
Audit committee diligence \\
Saudi Arabia
\end{tabular}

\section{A B S T R A C T}

This study aims to examine the effect of company experience on audit committee diligence among manufactured listed companies on Saudi Stock Exchange (Tadawul) for the period 2015-2017. The final sample of this study consists of 191 firm-year observations. Using the Pooled OLS regression, the study finds that there was a positive impact of company experience on audit committee diligence. The study provides insightful evidence to policy makers on the determinants influencing the audit committee diligence among manufacturing companies.

\section{Introduction}

According to Geroski (1995), the company's age has been widely used as a proxy for its experience in the world of business over the years, which is largely believed to have a positive impact on its performance. Similarly, corporate management has been acquiring significant information for a long period regarding capabilities and skills (Stinchcombe, 1965; Evans, 1987b). Gregory et al. (2005) add that companies that have been operating for many have had more opportunities to acquire and retain better earnings as compared with relatively younger firms. This provides the older firms with better opportunities to finance their operational growth. Umoren and Asogwa (2013) assert that older and well-organized companies with experience are likely to provide accurate and actual information since they tend to have a well-structured reporting system which is also cost-effective. According to Evans (1987a), the age of a company plays a critical role in the stability and growth of a company in the business environment and development. Abdullah, Ardiansah, and Hamidah (2017) indicate that good internet financial reporting is widely influenced by the age of a company. This is supported by Bhatt and Bhattacharya (2016) and Palaniappan (2017) who postulate that there is a positive between a company's performance and a company's age. The key elements of older companies regarding the development approach, organizational, and routine norms restrict the transformation of entrepreneurial actions and activities into positive performance and result (Ward and Mendoza recorded, 1996). According to agency theory, companies with high agency costs often tend to mitigate these costs by improving financial and operational activities through their auditing committees. According to Xie et al. (2003), the activities of the audit committee have a positive influence on the effectiveness of the monitoring role. Some reports indicate that a high level of activities can be related to the ability of the audit committee to effectively conduct its performance (Archambeault \& DeZoort, 2001). McMullen and Raghunandan (1996) state that

* Corresponding author

E-mail address: k.aljaaidi@psau.edu.sa (K. S. Aljaaidi) 
organizations that conduct fewer audit meetings tend to experience financial reporting experience. Therefore, experts cite that firms need to have frequent audit members' meetings to better their financial reporting since monitoring roles of the audit committee helps in improving the independence of the auditor. Other than improving financial reporting and auditors' independence, frequent audit members meeting is also believed to provide a better alternative observing activities (Greco, 2011; Collier \& Gregory, 1999; Vafeas, 1999; Laksmana, 2008; Sharma et al., 2009). Similarly, an active audit committee plays an important role in improving transparency in the security market, which in turn improves the company's book values and provides better protection of shareholders' interest (Yin et al., 2012; McMullen \& Raghunandam, 1996; DeZoort et al., 2002; Bagais \& Aljaaidi, 2020). DeZoort et al. (2002) assert that the frequency of the members meeting is primarily implemented as a proxy for the proficiency of the audit committee and to observe certain benefits of the financial reporting for companies with a wellstructured audit committee.

The main objective of this study is to provide information supporting the relationship between the age of a company and that audit committee diligence considering that no empirical studies are providing accurate evidence about such relationships. As such, this study will focus on expounding on the findings of the contemporary research works on the frequency of audit committee meetings (Menon \& Williams, 1994; Mendez and Garcia, 2007; Raghunandan \& Rama, 2007; Sharma et al., 2009; Greco, 2011; Al-Najjar, 2011; Thiruvadi, 2012; Yin et al., 2012; Maraghni \& Nekhili, 2014; Braswell et al., 2012) by adding new empirical evidence of the corporate governance utilizing recent data.

The remainder of the paper is organized as follows. The next section describes the sample, data and model of the study. Third section presents the results, tests and analysis. The final section concludes the study.

\section{Sample, data and model}

The population of interest comprises all manufactured companies listed on Saudi Stock Exchange (Tadawul) for the years 20152017. Our final sample comprises of 191 firm-year observations after excluding the outliers, missing and complete data. The number of audit committee meetings, total assets, debts, performance, and age were hand-collected from financial statements available on the web site of the Saudi Stock Exchange (Tadawul). Samples selected depicted in Table 1.

\section{Table 1}

$\underline{\text { Sample Selection }}$

Total observations

Observations discarded (outliers, missing and incomplete data)

Final sample

Total Observations 201 191

We control for several variables which are firm size (Yin et al., 2012; Menon \& Williams, 1994; Raghunandan \& Rama, 2007; Me'ndez \& Garc1'a, 2007; Sharma et al., 2009; Maraghni \& Nekhili, 2014; Qasim, 2020; Braswell et al., 2012), leverage (Yin et al., 2012; Me'ndez and Garc1'a, 2007; Collier \& Gregory, 1999), and profitability (Raghunandan \& Rama, 2007; Sharma et al., 2009; Yin et al., 2012; Qasim, 2020).

To address the impact of company age audit committee meeting frequency, we develop the following regression using a Pooled Ordinary least square model $O L S$ :

$$
\text { ACMEET }=\beta 0+\beta_{1} \text { FEXPER }+\beta_{2} \text { LASSET }+\beta_{3} \text { LEV }+\beta_{4} \text { ROE }+\mathrm{e}
$$

where

$\begin{array}{llll}\text { ACDEL } & \text { Number of meetings held during the year } & \text { LEV } & \text { Total book value of debt to total assets ratio } \\ \text { FEXPER } & \text { Number of years since the company is established } & \text { ROE } & \text { Return on equity } \\ \text { LASSET } & \log _{10} \text { of total assets } & \text { e } & \text { error term. }\end{array}$

\section{Results and analysis}

\subsection{Statistics and correlation}

The descriptive statistics are presented in Table 2, showing the mean, standard deviation, minimum and maximum of each variable in the sample data set. Table 2 displays that there is a significant range of variation among the considered sample of this study. The FEXPER'S mean is 28 years and it ranges from 2 to 62 and a standard deviation of 14. 227. It is shown that the range of $A C D E L$ is from 2 to 12 with an average of 5 and a standard deviation of 1.634. The mean of LASSET is 7601400637 
with a maximum of 97073302267 and a minimum of 19084462 and a standard deviation of 15674380196 . The $L E V$ ranges from 0.020 to 8.900 and mean of 0.449 and a standard deviation of 0.657 . The ROE ranges from 1.00 to .12 with an average of 0.00 and a standard deviation of .115 .

Table 2

Descriptive statistics

\begin{tabular}{ccccc}
\hline Variable & Mean & Minimum & Maximum & $\begin{array}{c}\text { Std. } \\
\text { Deviation }\end{array}$ \\
\hline FEXPER & 28 & 2 & 62 & 14.227 \\
ACDEL & 5 & 2 & 12 & 1.634 \\
LASSET & 7601400637 & 19084462 & 97073302267 & 15674380196 \\
LEV & .02 & 8.90 & .449 & .657 \\
ROE & 0.00 & 1 & .12 & .115 \\
\hline
\end{tabular}

Table 3

Correlation matrix of independent variables

\begin{tabular}{lcccc}
\hline & FAGE & LASSET & LEV & ROE \\
\hline FAGE & 1 & & & \\
LASSET & $-.198^{* *}$ & 1 & & \\
LEV & .024 & .101 & 1 & \\
ROE & .160 & -.054 & .096 & 1 \\
\hline
\end{tabular}

Table 3 confirms that the multicollinearity problem does not exist because the correlation matrixes among the variables do not exceed 0.90. All the variables have a correlation of equal to or less than .198. With regard to the (VIF) and the tolerance (1/VIF), in general, the existence of multicollinearity problems is detected if the variance inflation factors (VIF) is more than 10 and tolerance value is less than 0.10 (Hair et al., 2012). In the current study as shown by Table 4, the VIF and Tolerance results indicate that multicollinearity is not a problem to model explanation in this study.

Table 4

Multicollinearity statistics of assessing VIF and Tolerance values for the study Model

\begin{tabular}{|c|c|c|}
\hline \multirow[b]{2}{*}{ Variables } & \multicolumn{2}{|c|}{ Collinearity statistics } \\
\hline & $\begin{array}{c}\text { Variance Inflation Factor } \\
\text { (VIF) }\end{array}$ & $\begin{array}{c}\text { Tolerance Value } \\
(1 / \mathrm{VIF})\end{array}$ \\
\hline$F A G E$ & 1.066 & .938 \\
\hline LASSET & 1.050 & .953 \\
\hline$L E V$ & 1.018 & .983 \\
\hline$R O E$ & 1.036 & .965 \\
\hline $\begin{array}{l}\text { Mean VIF and } \\
\text { Tolerance }\end{array}$ & 1.043 & .960 \\
\hline
\end{tabular}

Table 5

Audit committee meeting frequency regression model

\begin{tabular}{lcccc}
\hline Variables & $\begin{array}{c}\text { Expected } \\
\text { Sign }\end{array}$ & Coef. & $\boldsymbol{t}$ & $\boldsymbol{P}>|\mathbf{t}|$ \\
\hline Test Variable & & & & \\
\hline FEXPER & + & .383 & 2.917 & $\mathbf{. 0 0 0}$ \\
Control Variables & & & & \\
LASSET & -.023 & -.300 & .765 \\
$L E V$ & -.193 & -2.543 & $\mathbf{. 0 1 2}$ \\
$R O E$ & -.109 & -1.419 & .158 \\
\hline \multicolumn{4}{l}{} \\
\hline
\end{tabular}

Bold $=$ significance at $1 \%, 5 \%$ and $10 \%$ (two-tailed significance)

Table 5 depicts the estimated regression coefficients for the regression model. The table illustrates that the $F$-value for the model is statistically significant at the $1 \%$ level, indicating that the overall model can be interpreted. The adjusted $R^{2}$ is 0.165 , indicating that the model has explained $16.50 \%$ of the variance in the audit committee meeting frequency. This indicates a good fit of the audit committee meeting frequency model. The regression results in Tables 5 show that the coefficient of FEXPER has a significantly positive association with audit committee diligence $(\mathrm{p} \mathbf{\mathbf { 0 . 0 1 }})$. This result is consistent with the agency theory prediction and the extant research suggestions (Geroski, 1995; Gregory et al., 2005; Stinchcombe, 1965; Evans, 1987a ,1987b).

\section{Conclusions}

Using the agency theory framework, this study has examined the effect of company experience on audit committee activity among 191 manufactured listed companies on Saudi Stock Exchange (Tadawul) for the period 2015-2017. The result has indicated to a positive impact of the company experience on the audit committee activity. The result of this study is in line with suggestions of the extant research (Geroski, 1995; Gregory et al., 2005; Stinchcombe, 1965; Evans, 1987a ,1987b). This indicates that experienced companies are characterized to have a high degree of monitoring effectiveness which appears clearly in the monitoring activity of their audit committees. Experienced companies' audit committees have a high level of activities to perform their duties effectively. This study extends the previous literature on corporate governance internal monitoring mechanisms, namely; audit committee diligence by testing empirical the effect of firm experience on the audit committee diligence. in the Saudi context where there is a lack of research in this area. Further, this study focus on the manufacturing sector in Saudi Arabia which has been neglected by the prior studies as a single industry. The findings of this study might have practical inferences for the Saudi stock market (Tdawul) that provide a new understanding regarding the extent to which an audit committee of manufacturing companies is active in a way to practice its monitoring responsibility and to protect the interests of shareholders. Similarly, the management of external auditors, bankers, and companies would also benefit from understanding the influential factors of the audit committee activities. The study has achieved its objectives, it is still subject to several limitations. Characteristics of audit committee and board of directors were excluded from the model of this study such as audit committee and board of directors' size, independence, multiple directorships, and financial experience. Future line of research may extend this study by including such characteristics. In addition, this study is tested in the setting of Saudi Arabia and among manufactured companies. Future line of research may replicate the model using other GCC countries' settings and different samples. 


\section{Acknowledgement}

This publication was supported by the Deanship of Scientific Research at Prince Sattam bin Abdulaziz University, Alkharj, Saudi Arabia.

\section{References}

Abdullah, M. D. F., Ardiansah, M. N., \& Hamidah, N. (2017). The effect of company size, company age, public ownership and audit quality on internet financial reporting. Sriwijaya International Journal of Dynamic Economics and Business, 1(2), 153-166.

Aljaaidi, K. S., \& Hassan, W. K. (2020). Energy industry performance in Saudi Arabia: Empirical evidence. International Journal of Energy Economics and Policy, 10(4), 271-277.

Al-Najjar, B. (2012) The determinants of board meetings: evidence from categorical analysis. Journal of Applied Accounting Research, 13, $178-90$.

Archambeault, D., \& DeZoort, F. (2001). Auditor opinion shopping and the audit committee: An analysis of suspicious auditor switches. International Journal of Auditing, 5(1), 33

Bagais, O., \& Aljaaidi, K. (2020). Corporate governance attributes and firm performance in Saudi Arabia. Accounting, 6(6), 923-930.

Braswell, M., Daniels, R. B., Landis, M., \& Chang, C. C. A. (2012). Characteristics of diligent audit committees. Journal of Business \& Economics Research (JBER), 10(4), 191-206.

Bhatt, R. R., \& Bhattacharya, S. (2017). Family firms, board structure and firm performance: evidence from top Indian firms. International Journal of Law and Management, 59(5), 699-717.

Collier, P., \& Gregory, A. (1999). Audit committee activity and agency costs. Journal of Accounting and Public Policy, 18(4-5), 311-332.

Evans, D. S. (1987a). Tests of alternative theories of firm growth. Journal of Political Economy, 95(4), 657-674.

Evans, D. S. (1987b). The relationship between firm growth, size, and age: Estimates for 100 manufacturing industries. The Journal of Industrial Economics, 35(4), 567-581.

Geroski, P. A. (1995). Market structure, corporate performance, and innovative activity. OUP Catalogue.

Greco, G. (2011). Determinants of board and audit committee meeting frequency. Managerial Auditing Journal, 26(3), 208-229

Gregory, B. T., Rutherford, M. W., Oswald, S., \& Gardiner, L. (2005). An empirical investigation of the growth cycle theory of small firm financing. Journal of Small Business Management, 43(4), 382-392.

Hair, J. F., Sarstedt, M., Pieper, T. M., \& Ringle, C. M. (2012). The use of partial least squares structural equation modeling in strategic management research: a review of past practices and recommendations for future applications. Long Range Planning, 45(5-6), 320-340.

Laksmana, I. (2008). Corporate board governance and voluntary disclosure of executive compensation practices. Contemporary Accounting Research, 25(4), 1147-1182.

Maraghni, I., \& Nekhili, M. (2014). Audit committee diligence in French companies: a question of independence or competence? Comptabilité-Contrôle-Audit, 20(2), 95-124.

McMullen, D. A., \& Raghunandan, K. (1996). Enhancing audit committee effectiveness. Journal of Accountancy, 182(2), 79.

Méndez, C. F., \& García, R. A. (2007). The effects of ownership structure and board composition on the audit committee meeting frequency: Spanish evidence. Corporate Governance: An International Review, 15(5), 909-922.

Menon, K., \& Williams, J. D. (1994). The use of audit committees for monitoring. Journal of Accounting and Public Policy, 13(2), 121-139.

Pucheta-Martínez, M. C., \& De Fuentes, C. (2007). The impact of audit committee characteristics on the enhancement of the quality of financial reporting: An empirical study in the Spanish context. Corporate Governance: An International Review, 15(6), 1394-1412.

Qasim, A. (2020). Examining the quality of audit committee work: An empirical examination of the determinants of audit committee diligence in the UAE. Calitatea, 21(176), 109-111.

Palaniappan, G. (2017). Determinants of corporate financial performance relating to board characteristics of corporate governance in Indian manufacturing industry. European Journal of Management and Business Economics, 26(1).

Raghunandan, K., \& Rama, D. V. (2007). Determinants of audit committee diligence. Accounting Horizons, 21(3), 265-279.

Sharma, V., Naiker, V., \& Lee, B. (2009). Determinants of audit committee meeting frequency: Evidence from a voluntary governance system. Accounting Horizons, 23(3), 245-263.

Stinchcombe, A. L. (2000). Social structure and organizations. Emerald Group Publishing Limited.

Thiruvadi, S. (2012). Gender differences and audit committee diligence. Gender in Management: An International Journal.

Umoren, A. O., \& Asogwa, I. E. (2013). Internet financial reporting and company characteristics: a case of quoted companies in Nigeria. Research Journal of Finance and Accounting, 4(12), 72-80.

Vafeas, N. (1999). Board meeting frequency and firm performance. Journal of Financial Economics, 53(1), 113-142.

Wolnizer, P. (1995). Are audit committees red herrings. Abacus, 31(1), 45-66.

Yin, F., Gao, S., Li, W., \& Lv, H. (2012). Determinants of audit committee meeting frequency: evidence from Chinese listed companies. Managerial Auditing Journal, 27(4), 425-444.

Xie, B., Davidson III, W. N., \& DaDalt, P. J. (2003). Earnings management and corporate governance: the role of the board and the audit committee. Journal of Corporate Finance, 9(3), 295-316.

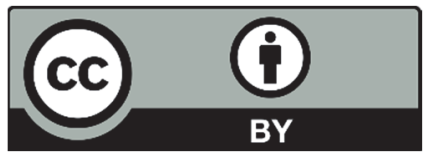

(C) 2021 by the authors; licensee Growing Science, Canada. This is an open access article distributed under the terms and conditions of the Creative Commons Attribution (CC-BY) license (http://creativecommons.org/licenses/by/4.0/). 